Lawrence of Arabia 
The publisher gratefully acknowledges the generous contribution to this book provided by The General Endowment Fund of the Associates of the University of California Press. 


\section{Lawrence of Arabia}

A Film's Anthropology

Steven C. Caton

UNIVERSITY OF CALIFORNIA PRESS

Berkeley · Los Angeles · London 
University of California Press

Berkeley and Los Angeles, California

University of California Press, Ltd.

London, England

(C) 1999 by

The Regents of the University of California

Library of Congress Cataloging-in-Publication Data

Caton, Steven Charles, 1950-

Lawrence of Arabia : a film's anthropology /

Steven C. Caton.

p. $\mathrm{cm}$.

Includes bibliographic references and index ISBN 0-520-21082-4 (alk. paper). ISBN 0-520-2 I083-2 (alk. paper)

I. Lawrence of Arabia (Motion picture)

2. Arabs in motion pictures. I. Title.

PN1997.L353C38 1999

$791.43^{\prime} 72$ DC2I

$98-362 I$

Printed in the United States of America

$\begin{array}{lllllllll}9 & 8 & 7 & 6 & 5 & 4 & 3 & 2 & \mathrm{I}\end{array}$

The paper used in this publication meets the minimum requirements of American National Standards for Information Sciences-Permanence of Paper for Printed Library Materials, ANSI Z39.48-I984. 
In memory of my mother, Hanni S. Caton (1912-96), with whom I enjoyed many a movie on the Late Night Show 
